\title{
Paideusis
}

\section{The Blowback on Heesoon Bai}

\section{Charles F. Scott}

Volume 16, Number 1, 2007

URI: https://id.erudit.org/iderudit/1072613ar

DOI: https://doi.org/10.7202/1072613ar

See table of contents

Publisher(s)

Canadian Philosophy of Education Society

ISSN

0838-4517 (print)

1916-0348 (digital)

Explore this journal

Cite this document

Scott, C. (2007). The Blowback on Heesoon Bai. Paideusis, 16(1), 81-83.

https://doi.org/10.7202/1072613ar

This document is protected by copyright law. Use of the services of Erudit (including reproduction) is subject to its terms and conditions, which can be viewed online.

https://apropos.erudit.org/en/users/policy-on-use/
This article is disseminated and preserved by Érudit.

Érudit is a non-profit inter-university consortium of the Université de Montréal, Université Laval, and the Université du Québec à Montréal. Its mission is to promote and disseminate research.

https://www.erudit.org/en/ 


\title{
The Blowback on Heesoon Bai
}

\author{
CHARLES SCOT'T \\ Simon Fraser University, Canada
}

Dennis, I was struck by the powerful introduction in your paper (Cato, 2006), "A World of Our Own: Heesoon Bai and the Flight into Romanticism," (Paideusis, Vol. 15, No. 2, pp. 119-121). I wholeheartedly agree with your concern about a descent into "a romanticism characterized ultimately by irrationalism, mysticism and obscurantism which renders it even more remote from educational practice" (Cato, 2006, p. 119). (As you likely know, there are at least two possible meanings to the word mysticism, both of which are significant in the context of Bai's paper: the first has to do the doctrine of the possibility of a direct union of the soul with God or the Ground of all Being through contemplative practices, while the second has to do with forms of obscure thought and vague speculations; I take it that, like I am, you are referring to the latter meaning.)

Even more, I am impressed with the Socratic concern you express in dismissing "philosophical somersaults" and instead asking: ". . . but what about the real-life blowback down at the office." Excellent question: I'm happy to see you bring philosophy down from rarefied airs to the asphalt of daily living. My impression is that Socrates felt that it was only when the rubber hits the road that our philosophy established validity and, through the data gleaned from our repeated practice, reliability. I think it might be interesting to check Bai's educational efforts in light of your entirely legitimate concern, examining her pedagogical, professional, and interpersonal practices as they are informed by her philosophy to see if there is any validity to her practice and, more to the point, to your claims about her.

First, some disclosure. I am a graduate student in the faculty of education at SFU. I read some of Dr. Bai's work and contacted her, thinking of applying to the faculty for entry into graduate school. She was gracious enough to exchange several emails with me even before I'd been accepted into the graduate program, also spending over an hour meeting with me to talk about philosophy, education, and my possible entrance into the program. I have taken more than one graduate-level class with her. I worked with her and others over a period of several months preparing for a presentation given at a major conference. I have been able to observe her role in the resurrection of Paideusis. She has helped me with the writing of a SSHRC grant proposal. She has been supportive in many ways, including once when she helped me in the midst of what I'm told is an almost inevitable, minor meltdown during the rigors of the doctoral program.

All of which is exactly the point. I have spent a significant amount of time working with her, not only in these professional contexts, but also in more informal, friendly settings; I mention all this to add some authority to my claim that she is gracious: she personifies courtesy and respect, not to mention an infectious good humor. She is accommodating and generous: she has provided numerous opportunities for graduate students, she routinely helps colleagues and associates; indeed, she is accommodating almost to a fault. She is a relentlessly hard worker as an academic: her publication record speaks for itself, she has served on the executive committee of the faculty for many months, and she serves the academic community and the public in too many ways to list here. She is a wonderful teacher: her classes are immensely popular with students, she has served on dozens of thesis committees, she has been awarded an "Excellence in Teaching" award from SFU, and she has received accolades from

(C) Copyright 2007. The author, Charles Scott, assigns to Paideusis the right of first publication and educational and non-profit institutions a non-exclusive license to use this document for personal use and in courses of instruction provided that the article is used in full and this copyright statement is reproduced. Any other usage is probibited without the express permission of the author. 
people like Douglas Todd, award-winning ethics and religion journalist for The Vancouver Sun. She is, of course, the editor of Paideusis, and in what is just a delicious irony, her significant efforts helped resurrect the journal from oblivion, allowing it to serve as a vehicle for your paper.

(Am I biased? Likely. Does this invalidate my data? I would suggest that my information has more validity than the declarative sentence which concludes your paper, Dennis; I have spent time working with her and in being able to observe her actions from a fairly close range.)

I will quote here from two course outlines of hers. The first is from a graduate course on moral and social philosophy:

Ethics has us ask this quintessential question of individual choice and responsibility. How should I live? Ethics also reminds us that our lives-all sentient lives-are thoroughly and inextricably interdependent. Hence, ethics requires us to consider individual choice and responsibility in terms of world citizenship ("moral agency") in multiple communities .... As well, many classical traditions have understood Ethics as an inquiry concerning the ways of living well ("the art of living"). To combine these two themes of moral agency and the art of living, we thus ask in Ethics: How shall individuals choose responsibly to live well with and for each other? (Bai, 2005).

There doesn't seem to be much of a match with: "[R]otating slowly in the warm, darkened space of her own interiority", and "living in a world of her own," as you put it, Dennis. From the outline of her doctoral seminar on the history of educational philosophy:

Theories concerning education are fundamentally about theories of being human creatures .... Who or what is a human being? In this sense, education is an enactment of Philosophical Anthropology. We teach to the image of humanity we have before us. Different images of humanity, as portrayed in different times and places, call for different theories of what to teach (curriculum) and how to teach (pedagogy) (Bai, 2006).

One of the significant themes I have noticed in working with her is the notion of relationality. Of course, this theme would be obvious in a course on moral and social philosophy. But it proved to be just as central in our examination of educational theory from Plato to the postmodernists. The image we have of humanity is based on and in turn informs our relationships with others and the world at large. The same is true for our actions. And I notice that Heesoon addresses this in her paper, writing that dialogue between individuals consists of a critical, rigorous, compelling, mutual examination of thoughts, perceptions, and impressions. She later calls for the cultivation of "humane sensibility or benevolence" in the context of a larger, integrated cultivation of an expanded awareness of others; she makes this pretty clear when she writes: “. . . this process of becoming human properly pertains to the communicative, interactive realm of social-cultural-political interrelationships that define the progressively expanding order of family, community, country, world, nature, and beyond" (Bai, 2006b, p.16). I'm puzzled as to how you can think this solipsistic, Dennis. As if this weren't enough, she pointedly refers to "teaching by the body," recognizing the significance of the personality and life of the teacher and learner(s) in the contexts of their everyday relationships.

I won't try to defend her advocacy of contemplative arts-although I fully support it, as well as the mysticism (in the other sense of the word) that informs these arts-except to say that a nondiscursive state of awareness is not necessarily antithetical to rational thought as you claim (I would suggest it is a both-and rather than an either-or proposition). I will, however, suggest that the example of her daily life as a scholar, associate, and friend offers plenty of compelling evidence that Heesoon not only embodies her philosophy of nurturing the humanity in all, but that it also works for the benefit of herself and others. The blowback at the office is pretty good, Dennis. In lieu of any substantive data on Heesoon and her practice that you might have, I offer an invitation that may have epistemological value for you: come on out and take a look for yourself. 


\section{References}

Bai, H. (2005). Course outline: Seminar in social and moral philosophy and education. Unpublished document.

Bai, H. (2006a). Course outline: Seminar in the history of educational theory. Unpublished document.

Bai, H. (2006b). Philosophy for education: Towards human agency. Paideusis, 15(2), 7-19. Retrieved January, 15, 2007 from http://journals.sfu.ca/paideusis/index.php/paideusis/article/viewFile/ $47 / 9$

Cato, D. (2006). A world of our own: Heesoon Bai and the flight into romanticism. Paideusis 15(2), 119121. Retrieved January, 15, 2007 from http://journals.sfu.ca/paideusis/index.php/paideusis/ article/viewFile/84/39 